\title{
Organizational Differences among Universities in Three Socioeconomic Contexts: Finland, Spain and Ecuador. Relational Coordination Approach
}

\author{
Cristina Checa-Morales ${ }^{1,2,3, *}$, Carmen De-Pablos-Heredero ${ }^{2,4} \mathbb{D}$, Angela Lorena Carreño $5 \mathbb{D}$, Sajid Haider 6 \\ and Antón García ${ }^{3}$ (D)
}

Citation: Checa-Morales, C.; De-Pablos-Heredero, C.;

Carreño, A.L.; Haider, S.; García, A. Organizational Differences among Universities in Three Socioeconomic Contexts: Finland, Spain and Ecuador Relational Coordination Approach. Educ. Sci. 2021, 11, 445. https:// doi.org/10.3390/educsci11080445

Academic Editors: Sandra Raquel Gonçalves Fernandes, Marta Abelha and Ana Teresa Ferreira-Oliveira

Received: 22 July 2021

Accepted: 18 August 2021

Published: 20 August 2021

Publisher's Note: MDPI stays neutral with regard to jurisdictional claims in published maps and institutional affiliations.

Copyright: (c) 2021 by the authors Licensee MDPI, Basel, Switzerland. This article is an open access article distributed under the terms and conditions of the Creative Commons Attribution (CC BY) license (https:/ / creativecommons.org/licenses/by/ $4.0 /)$.
1 International Doctoral School (EID), Rey Juan Carlos University, 28008 Madrid, Spain

2 Department of Business Economics (Administration, Management and Organization), Applied Economics II and Fundamentals of Economic Analysis, Rey Juan Carlos University, 28032 Madrid, Spain; carmen.depablos@urjc.es

3 Animal Science Department, University of Cordoba, Rabanales University Campus, 14071 Cordoba, Spain; pa1gamaa@uco.es

4 Area of Business Economics, ESIC University, 28223 Madrid, Spain

5 Faculty of Administrative and Economic Sciences, Technical University of Manabí, Portoviejo 130105, Ecuador; angela.carreno@utm.edu.ec

6 Department of Management Sciences, COMSATS University Islamabad, Vehari Campus, Vehari 61100, Pakistan; sajidhaider@ciitvehari.edu.pk

* Correspondence: c.checa.2019@alumnos.urjc.es

\begin{abstract}
The knowledge of local culture is essential to establish competitive strategies in higher education. The objective of this research was to identify the organizational differences among three universities with different international contexts and satisfaction level. An approach was made regarding Relational Coordination (RC) attributes: accurate, frequent and problem-solving communication, shared knowledge, mutual respect and shared goals, by discriminant analysis method. A random sample of 300 students, 100 belonging to each university, was surveyed on the 23 RC variables in 2017-2018. First, the RC variables were evaluated by general linear model (GLM). The three universities-Arcada University of Applied Science (ARCADA) in Finland, University of Cordoba (UCO) in Spain and Agricultural Polytechnic of Manabi "MFL" (ESPAM) in Ecuador—and the two levels of student satisfaction-Low and High-were used as fixed factors. Second, a discriminant model was built with RC variables. A higher level of RC practices concerning to accurate, frequent and problem-solving communication achieved higher levels of satisfaction, regardless of the universities' socioeconomic context. RC differentiation among three universities showed that shared goals with lecturers and administrative officers and problem-solving communication among classmates were the variables with the highest discriminant power. Two clusters were obtained, where UCO was the most differentiated university. In conclusion, organizational practices made a difference among the three universities. Discriminant analysis can be adapted and extended to different universities to improve quality.
\end{abstract}

Keywords: relational coordination; student satisfaction; higher education; communication; discriminant analysis

\section{Introduction}

As a key to value creation in modern societies, improvement in higher education has received considerable attention from policy makers [1,2]. The way Higher Education Institutions have put into practice organizational learning is considered a key element [3]. Organizational learning is interpersonal and relational, and it has often involved learning to coordinate work in new ways [4]. Coordination has been explained by organization design and contingency theorists such a Kundu et al. [5], as an information-processing problem. Some authors such a Faraj and Sproull [6] and Margalina et al. [7] have perceived 
coordination as shared understanding of work, and the context in which the activity is carried out has been defined as a relational process. According to Fu et al. [8], coordination is an important management strategy which helps organizations to improve efficiency and effectiveness.

Gittell [9] defined relational coordination ( $\mathrm{RC}$ ) as a mutually reinforcing process of communicating and relating for the purpose of task integration. $\mathrm{RC}$ is a mechanism based on human factors. Even though excellence is measured by results, it is generated in intangible, personal and human processes [10]. The RC model could become a helpful tool to measure and encourage effective coordination. RC is based on human relationships among emotional beings [11]. For this reason, it attempts to group together all the connections between them, not merely as tasks, tools or technical needs, but rather in real ways to make it possible for people to work efficiently. RC has been built around work coordination, by considering all aspects of team's relationships. It recognizes, therefore, the need for the relational side of coordination to achieve organizational effectiveness [12,13].

Gittell et al. [14] structured the RC model around two dimensions: communication and relationships. The communication dimensions are: (i) frequent communication helps to establish relationships via roles through the proximity generated because of repeated interaction; (ii) timely communication, communication provided on time; (iii) accurate communication, in the context of relevant information, this plays a critical role in the effectiveness of a group's tasks performance; (iv) problem-solving communication, referred to effective coordination to solve problems. The relationship dimensions are: (i) shared goals: these play a key role in the coordination of highly interdependent tasks; (ii) shared knowledge: communication among those involved in the various tasks that constitute a process is not always effective because of different social backgrounds, training and experience; (iii) mutual respect, that generates an effective coordination, because participant's profiles in the same process value the contribution of others and consider the impact of their own actions in others too.

Understanding the RC factor relationships helped to know how resources can be organized best in order to maximize an institution's performance [10,11]. Existing research showed that RC was positively linked to organizational performance in several sectors. Gittell et al. [11] applied it to different medical units inside hospitals and observed that units with higher levels of RC produced best performance. Havens et al. [15] explained higher levels of job satisfaction, work engagement and decrease of burnout from the RC perspective. Haider et al. [13] applied the RC to the banking industry to explain the relationship between high performance work systems and job satisfaction. Gallego et al. [16,17] and Margalina et al. [7] applied the RC model to explain best results in online systems in higher education. The model was also applied to face-to-face learning. At Quevedo State Technical University (Ecuador), a typology of organizational models was built [18]. In addition, the level of quality in education of Agricultural Polytechnic of Manabi "MFL" and Quevedo State Technical University [19] was estimated. Furthermore, Checa et al. [20] located RC factors oriented towards sustainability in higher education.

Quality is an important performance indicator for education, and it is one of the main issues examined by modern scholars and practitioners from the international education market [21]. The main problem lies in the subjectivity of the concept of quality, which makes it difficult to measure [22]. According to Gallego et al. [16], an indicator to measure the quality was the degree of students' satisfaction. Satisfaction showed a customer orientation, linking what it is expected from one student with the obtained result [23]. Student's perceived satisfaction showed the efficiency of organizations at different areas of activity: Academic services, administrative services, teaching staff, training programs, etc. [24]. However, there is still a lack of empirical research that examines the relationship between RC and students' satisfaction to solve some questions such us: How deep is that relationship? Does an improvement in RC increase student satisfaction? Furthermore, in the current literature, the findings are based on cases that can hardly be extended to other universities. Addi-Raccah and Gavish [25], Lee and Yu [26] and Noël et al. [27] identified 
organizational differences through discriminant analysis. A comparison among universities allows identifying the key organizational factors that differentiate them. This can enable the design of strategic measures oriented to improve the quality of performances.

We pose the following research questions: (RQ1) Do universities located in developed countries showed a higher level of RC? (RQ2) Do the most satisfied students have a higher level of RC? (RQ3) Is it possible to build an organizational model that differentiates the three institutions?

Therefore, the objective of this study was to identify the organizational differences among three universities with different socioeconomic contexts and two levels of student satisfaction, from the RC perspective. The cases of Arcada University of Applied Science (ARCADA) in Finland, University of Cordoba (UCO) in Spain and Agricultural Polytechnic of Manabi "MFL" (ESPAM) in Ecuador with different satisfaction levels and socioeconomic contexts were selected. The analysis was developed in two stages. In the first stage, considering the 23 organizational variables proposed, those variables with significant differences among the three universities and between the two levels of satisfaction by general linear model (GLM) were identified. In the second stage, the organizational differences among the three universities were explained by discriminant analysis.

\section{Socioeconomic Contexts}

The knowledge of local culture and the socioeconomic situation are essential to establish competitive educational leadership and management strategies [28]. In this research, three universities were selected as representative instruments of three international socioeconomic contexts with different organizational structures. ARCADA represented Finland, which has a high Gross Domestic Product (GDP) (Table 1). This university is in the position 18 out of 35 in the ranking of Finnish Universities [29]. UCO represented Spain, which has a medium GDP (Table 1). UCO is a non-private university and appears in position 53 out of 120 in the ranking of Spanish universities [30]. Ecuador presented the lowest GDP (Table 1) and was represented by ESPAM. This is university is in the position 41 out of 61 universities in Ecuador [31]. In Table 1, the main differences between the three socioeconomic contexts and the positions in the higher education rankings of the three universities were shown.

The three countries were compared using the Program for International Student Assessment (PISA) report. This study carried out by the countries belonging to the Organization for Economic Cooperation and Development (OECD), measures the academic performance of students according to subjects such as mathematics, science and reading. Finland and Spain showed their data in the regular PISA report [32,33], while Ecuador presented their data in the "PISA for development" or PISA-D report [34], an OECD initiative for low-and middle-income countries. Ranking Web of Universities showed the position of each university worldwide [35]. 
Table 1. Socioeconomic contexts (pre-COVID 19).

\begin{tabular}{|c|c|c|c|c|c|c|c|c|c|c|c|c|c|c|c|}
\hline \multicolumn{6}{|c|}{ Characteristics of the Country } & \multicolumn{9}{|c|}{ PISA Report [32,33]/PISA-D Report [34] } & \multirow[t]{2}{*}{ Ranking $^{3}$} \\
\hline Country & Population & $\mathrm{GDP}^{1}$ & $\begin{array}{l}\text { Public } \\
\text { univ. }\end{array}$ & $\begin{array}{l}\text { Non-public } \\
\text { univ. }\end{array}$ & $\begin{array}{l}\text { Political } \\
\text { System }\end{array}$ & $\begin{array}{l}\text { Mathematics } \\
\text { and science } \\
\text { average } \\
\text { (pts.) }\end{array}$ & $\begin{array}{l}\text { High perfor- } \\
\text { mance } \\
\text { students (\%) }\end{array}$ & $\begin{array}{l}\text { Socioeconomic } \\
\text { impact }(\%)^{2}\end{array}$ & $\begin{array}{l}\text { Student per- } \\
\text { formance } \\
\text { trend }\end{array}$ & $\begin{array}{l}\text { Staff and } \\
\text { resources } \\
\text { quality }\end{array}$ & $\begin{array}{l}\text { Qualified } \\
\text { teaching by type } \\
\text { of centre (\%) }\end{array}$ & $\begin{array}{c}\text { Bullying cases } \\
(\%)\end{array}$ & $\begin{array}{l}\text { Lifestyle } \\
\text { satisfaction } \\
(\%)\end{array}$ & $\begin{array}{c}\text { Student } \\
\text { growth } \\
\text { mindset (\%) }\end{array}$ & \\
\hline Finland & $5,515,525$ & 48,280 & 13 & 22 & $\begin{array}{c}\text { Parliamentary } \\
\text { republic }\end{array}$ & $\begin{array}{c}\text { Mathem. } \\
\quad 520 \\
\text { Science } 552 \\
\end{array}$ & 12 & 11 & Decrease & Remain & $\begin{array}{c}\text { Favoured: } 94 \\
\text { Disadvantaged: } \\
91 \\
\end{array}$ & 18 & 78 & 67 & $\begin{array}{c}\text { ARCADA }= \\
4589\end{array}$ \\
\hline Spain & $46,797,754$ & 29,350 & 64 & 56 & $\begin{array}{c}\text { Parliamentary } \\
\text { monarchy }\end{array}$ & $\begin{array}{c}\text { Mathem. } \\
481 \\
\text { Science } 483\end{array}$ & 4 & 10 & Stable & Shortage & $\begin{array}{l}\text { Favoured: } 94 \\
\text { Disadvantaged: } \\
98\end{array}$ & 17 & 74 & 62 & $\mathrm{UCO}=679$ \\
\hline Ecuador & $17,084,359$ & 6090 & 30 & 31 & $\begin{array}{c}\text { Presidential } \\
\text { constitutional } \\
\text { republic }\end{array}$ & $\begin{array}{l}\text { Mathem. } \\
377 \\
\text { Science } 399\end{array}$ & 1.4 & 25 & Decrease & Shortage & No data & No data & 87 & No data & $\underset{15,330}{\mathrm{ESPAM}}=$ \\
\hline
\end{tabular}

${ }^{1}$ Gross Domestic Product: \$/person/year. ${ }^{2}$ Status students over performance. ${ }^{3}$ Ranking web universities [35]. 
Arcada University of Applied Science (ARCADA) is a private university located in Finland, in Northern Europe. It is composed of 2443 students, 165 employees, 4 educational departments, 17 grade programs and 10 Master programs. U-Multirank ranking evaluates five dimensions of higher education centers (teaching and learning, research, knowledge transfer, international orientation and regional engagement). ARCADA overall profile showed higher performance on several indicators, with " $\mathrm{A}$ " scores (very good) overall. According to U-Multirank [36], ARCADA was strongest in Regional Engagement. ARCADA was in position 4589 out of 30,585 in the Ranking Web of Universities [35]. Within the three world rankings that classify the top 1000 universities, University of Cordoba (UCO) was ranked at position 800 in The Higher Education World Universities Ranking [37], position 700-800 in the Shanghai Ranking [38] and position 101-150 in QS World Universities Ranking [39]. It presented a medium size dimension with 21,000 students, 1200 lecturers, 700 workers, 47 undergraduate studies and more than 50 postgraduate studies. Finally, it was classified in the position 686 out of 30,585 in the Ranking Web of Universities [35]. Moreover, Agricultural Polytechnic of Manabi, ESPAM, is a public institution located in Ecuador. It was graded with " $\mathrm{C}$ " category by the Council of Evaluation, Accreditation and Quality Assurance of Upper Education (CEAACES) [40]. This is a ranking applicable to Ecuadorian universities exclusively. This classification is distributed in a decreasing way from category " $\mathrm{A}$ " to " $\mathrm{D}$ ". In this case, 2811 students and 176 employees compose ESPAM, and it offers 8 grade programs. In addition, it was ranked 15,330 out of 30,585 in the Ranking Web of Universities [35].

\section{Materials and Methods}

\subsection{Data Collection and Survey}

A stratified random sample composed of 300 surveyed students, 100 from each university, was collected during the period 2017-2018. The initial data started from a database for each university, made up of 200-1000 data each one. Incomplete surveys and those that showed logical inconsistencies were deleted. Finally, a group of 100 surveys from each university was randomly selected with the random function of the spreadsheet software, making up the complete database with 300 surveys. The survey included 33 items: 4 socioeconomic (age, gender, character public/private, size), 6 of students' perceived satisfaction and 23 related to RC. The survey's reliability was verified by means of Cronbach's alpha, with values greater than 0.7 , acceptable to confirm internal consistency: communication dimension (0.703), relationship dimension (0.831) and satisfaction (0.793) (Table 2). The complete survey showed a Cronbach's alpha of 0.87 [20,41].

The 23 items of the RC model focused on the mechanisms involved in organizational practices are shown in Table 2. 11 variables of the communication dimension, 12 of relationship dimension and 6 related to the level of student satisfaction were used. The students answered each question of the survey (Table S1) as many times as profiles were observed at the university. Then, each relational coordination variable was disaggregated into the following profiles: lecturers, administrative officers, classmates, student representatives and me (myself), as a control variable. A Likert scale metric was used, from 1 (infrequent) to 5 (very frequent). In this case, the intervals between the points on the scale corresponded to empirical observations in the metric sense [42]. A visual analog scale was displayed on each survey question presented to the students. 
Table 2. Relational coordination and satisfaction variables.

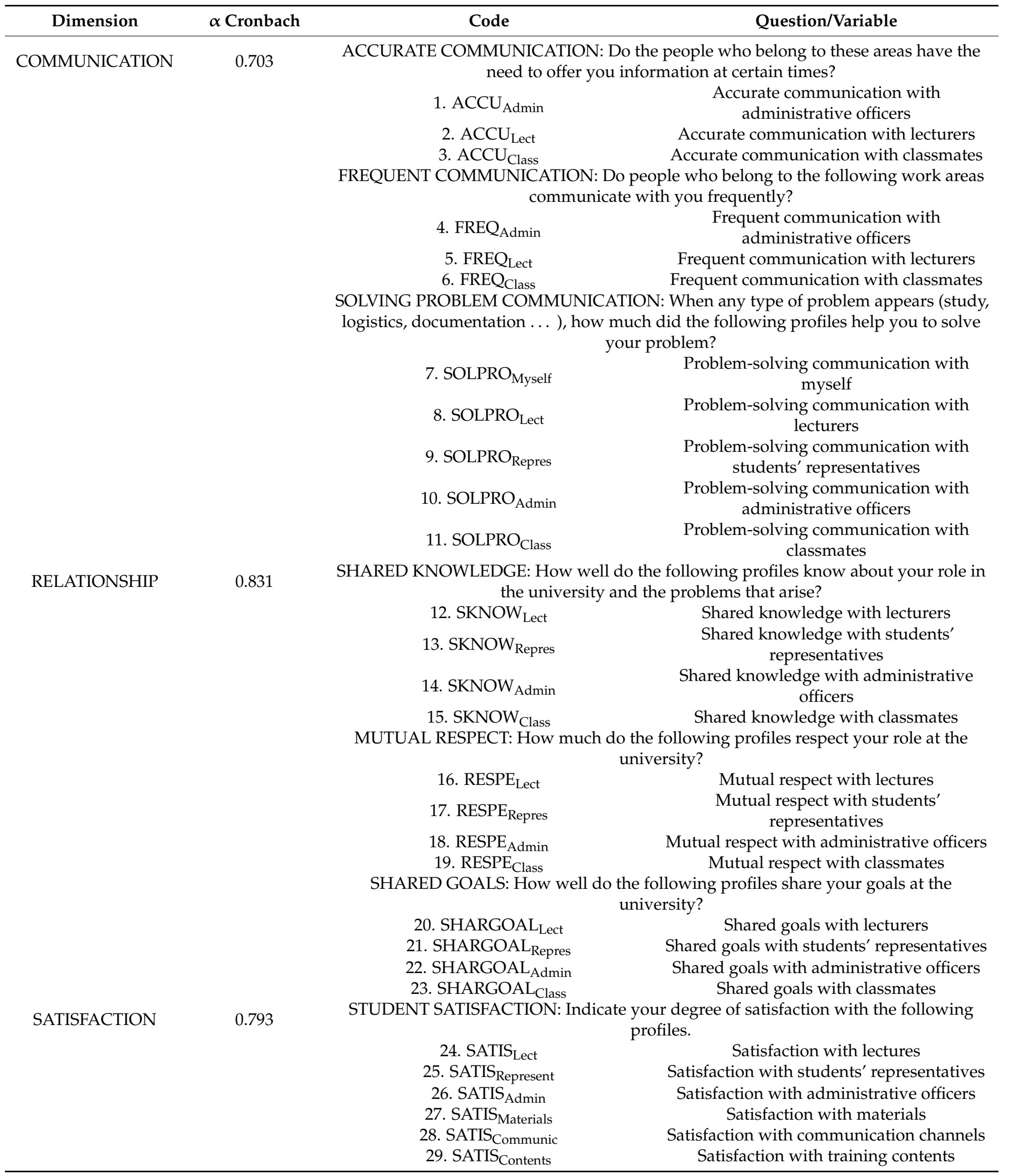

The proposed indicator of satisfaction was based on the student's satisfaction level $[7,16,43]$. This indicator was obtained from variables 24-29, related to profiles of conferences, student representatives, administrative officers, materials, communication channels, training con- 
tent. The descriptive statistics of trend, dispersion and position of the satisfaction variable were calculated (Figure S1). In each university the median ranges between 18-20 points and for the total sample of 19 points. Therefore, two levels were determined: 19 points was used as border: less than 19, "Low satisfaction" and more than 19, "High satisfaction" [19,20]. Later, satisfaction level was understood as fixed or independent variable.

\subsection{Statistical Analysis}

The normality of the data distribution was evaluated using the Kolmogorov-Smirnov test (with the Lilliefords correction) and a Levene test was used to evaluate the homogeneity of variance. For those variables that did not show a normal distribution, the Bartlett test was applied to assess if the data had equal variances.

In the first stage, to answer RQ1 and RQ2, the RC variables influenced by the university (socioeconomic context) and the level of satisfaction were identified. 23 variables of RC were compared using the general linear model (GLM). The three universities (ARCADA, ESPAM and UCO) and two satisfaction levels (Low and High) were used as fixed factors. The interactions between both factors were also considered [43]. Three levels: ${ }^{*} p$-value < $0.05 ;{ }^{* *} p$-value $<0.01$ and ${ }^{* * *} p$-value $<0.001$ were considered. The test allowed determining which pairs of means differed significantly and to study data whose error did not conform to the normal distribution and non-constant variances. The test allowed determining which pairs of means differed significantly and to study data whose error did not conform to the normal distribution and non-constant variances [43].

Secondly, an organizational model was built using a canonical discriminant analysis to answer to RQ3. This analysis allows studying the concrete relationships that exist among discriminated groups (universities) and their degree of association [44]. The coefficients of the discriminant model show the relative contribution of the variables to the model. The higher the value of the F-remove coefficient, the greater the contribution to group discrimination $[45,46]$. Therefore, variables with a $p$-value $<0.05$ were accepted and a model with highest percentage of correctly classified cases was selected. The most discriminant variables were calculated applying the F of Snedecor, Wilks' Lambda and the 1-Tolerance. High values of $F$ for each variable indicated that the means of each group were widely separated. Small Lambda values showed that the variable discriminates well among groups. Variables with a high percentage of tolerance (1-Toler) were selected [26]. Statistical analyses were performed using the STATISTICA 12.

\section{Results}

The three universities showed an average age of students less than 25 years in $86 \%$ of the sample ( $p$-value $<0.05)$. Regarding gender, the distribution was uniform in ARCADA. However, in UCO most of the students were women $(p$-value $<0.001)$ and in ESPAM most of the students were men $(p$-value $<0.05)$. Regarding the field of knowledge, significant differences were found among the three universities. In ARCADA $100 \%$ of the data corresponded to the Social Sciences ( $p$-value $<0.001$ ), in UCO the Health Sciences predominated $(90 \%$; $p$-value $<0.001)$ and in ESPAM the Engineering Areas obtained the highest percentage $(72 \% ; p$-value $<0.05)$. The sociodemographic indicators of the sample are shown in Table 3. 
Table 3. Sociodemographic distribution of the sample (\%).

\begin{tabular}{ccccccccccc}
\hline & \multicolumn{3}{c}{ Age } & \multicolumn{3}{c}{ Gender } & \multicolumn{3}{c}{ Field of Knowledge } \\
\hline & $<25$ & $\geq 25$ & $p$-Value & Male & Female & $p$-Value & $\begin{array}{c}\text { Social } \\
\text { sciences }\end{array}$ & Engineering & $\begin{array}{c}\text { Health } \\
\text { sciences }\end{array}$ & $p$-Value \\
\hline ARCADA & 86 & 14 & ns & 54 & 46 & ns & 100 & - & - & $* * *$ \\
UCO & 88 & 12 & ns & 30 & 70 & $* * *$ & - & 10 & 90 & $* * *$ \\
ESPAM & 83 & 17 & ns & 56 & 44 & $*$ & 15 & 72 & 13 & $*$ \\
TOTAL & 86 & 14 & ns & 46 & 54 & $* * *$ & 38 & 27 & 35 & $* * *$ \\
\hline
\end{tabular}

${ }^{*} p$-value $<0.05 ;{ }^{* *} p$-value $<0.01 ;{ }^{* * *} p$-value $<0.001 ; \mathrm{ns}=$ not significantly different.

The three universities reached relational coordination values close to the average (69.87 $\pm 0.78 ; \mathrm{CV}=0.19)$. Regarding satisfaction, $\mathrm{UCO}$ obtained the lowest level (18.25 \pm $0.44 ; C V=0.24)$ and ARCADA (19.44 $\pm 0.53 ; C V=0.27)$, the highest one. The dispersion coefficient was low in the three universities (data not presented).

\subsection{Identification of Organizational Differences}

GLM results are shown in Table 4. Significant differences were found in most of the variables of RC by university and satisfaction ( $p$-value $<0.05)$. $82.61 \%$ of the RC variables showed significant differences by university. The highest $R C$ values were observed at ESPAM and UCO, while ARCADA showed lower values. ARCADA showed significant differences in the variables related to solving problem communication and shared knowledge with the administrative officers. In UCO significant differences were found, highlighting the frequent communication, shared knowledge and mutual respect related to classmates. Lastly, ESPAM showed significant differences in accurate and frequent communication variables, and shared knowledge and goals were the variables that stood out, relating to lectures.

Table 4. Relational coordination by university and satisfaction level (Mean $\pm \mathrm{SE}$ ).

\begin{tabular}{|c|c|c|c|c|c|c|c|c|}
\hline \multirow[t]{2}{*}{ Variable } & \multicolumn{3}{|c|}{ University (A) } & \multicolumn{2}{|c|}{ Satisfaction Level (B) } & \multicolumn{3}{|c|}{$p$-Value } \\
\hline & ARCADA & $\mathrm{UCO}$ & ESPAM & Low & High & $\begin{array}{l}\text { University } \\
\text { (A) }\end{array}$ & $\begin{array}{l}\text { Satisfaction } \\
\text { level (B) }\end{array}$ & $\begin{array}{c}\text { Interactions } \\
(\mathrm{A} \times \mathrm{B})\end{array}$ \\
\hline 1. $\mathrm{ACCU}_{\mathrm{Admin}}$ & $2.75^{\mathrm{a}} \pm 0.10$ & $2.60^{\mathrm{a}} \pm 0.10$ & $3.38^{b} \pm 0.10$ & $2.67 \pm 0.09$ & $3.15 \pm 0.08$ & $* * *$ & $* * *$ & ns \\
\hline 2. ACCU Lect & $3.57^{\mathrm{a}} \pm 0.09$ & $3.77^{\mathrm{ab}} \pm 0.09$ & $3.95^{\mathrm{b}} \pm 0.09$ & $3.60 \pm 0.07$ & $3.92 \pm 0.07$ & $* *$ & $* *$ & $* *$ \\
\hline 3. ACCU Class & $3.67^{\mathrm{a}} \pm 0.10$ & $3.76^{\mathrm{a}} \pm 0.10$ & $3.84^{\mathrm{a}} \pm 0.10$ & $3.67 \pm 0.08$ & $3.84 \pm 0.08$ & ns & ns & ns \\
\hline 4. FREQ $\mathrm{Admin}$ & $2.54^{b} \pm 0.09$ & $1.99^{\mathrm{a}} \pm 0.09$ & $2.81^{\mathrm{c}} \pm 0.10$ & $2.16 \pm 0.08$ & $2.74 \pm 0.07$ & $* * *$ & $* * *$ & $* *$ \\
\hline 5. FREQ Lect & $3.44^{\mathrm{a}} \pm 0.09$ & $3.54^{\mathrm{a}} \pm 0.09$ & $3.83^{b} \pm 0.09$ & $3.36 \pm 0.08$ & $3.84 \pm 0.07$ & $* *$ & $* * *$ & ns \\
\hline 6. FREQ ${ }_{\text {Class }}$ & $4.08^{\mathrm{ab}} \pm 0.09$ & $4.30^{b} \pm 0.09$ & $4.00^{\mathrm{a}} \pm 0.09$ & $4.08 \pm 0.08$ & $4.17 \pm 0.07$ & ns & ns & ns \\
\hline 7. SOLPRO Myself & $4.20^{\mathrm{ab}} \pm 0.08$ & $4.43^{b} \pm 0.08$ & $4.18^{\mathrm{a}} \pm 0.08$ & $4.29 \pm 0.07$ & $4.25 \pm 0.07$ & ns & ns & ns \\
\hline 8. SOLPRO Lect & $3.04^{\mathrm{a}} \pm 0.08$ & $3.04^{\mathrm{a}} \pm 0.08$ & $3.11^{\mathrm{a}} \pm 0.08$ & $2.87 \pm 0.07$ & $3.26 \pm 0.07$ & ns & $* * *$ & ns \\
\hline 9. SOLPRO Repres & $2.13^{\mathrm{a}} \pm 0.11$ & $2.51^{\mathrm{b}} \pm 0.11$ & $2.47^{\mathrm{b}} \pm 0.11$ & $2.18 \pm 0.09$ & $2.56 \pm 0.09$ & $*$ & $* *$ & ns \\
\hline 10. SOLPRO Admin & $2.50^{\mathrm{b}} \pm 0.09$ & $2.05^{\mathrm{a}} \pm 0.09$ & $2.46^{\mathrm{b}} \pm 0.09$ & $2.09 \pm 0.08$ & $2.59 \pm 0.07$ & $* * *$ & $* * *$ & ns \\
\hline 11. SOLPRO & $3.43^{b} \pm 0.10$ & $3.78^{c} \pm 0.10$ & $2.95^{\mathrm{a}} \pm 0.10$ & $3.37 \pm 0.08$ & $3.40 \pm 0.08$ & $* * *$ & ns & ns \\
\hline 12. SKNOW & $3.04^{\mathrm{ab}} \pm 0.11$ & $2.85^{\mathrm{a}} \pm 0.10$ & $3.16^{b} \pm 0.10$ & $2.81 \pm 0.09$ & $3.23 \pm 0.08$ & ns & $* *$ & ns \\
\hline 13. SKNOW Repres & $2.36^{\mathrm{a}} \pm 0.12$ & $2.21^{\mathrm{a}} \pm 0.11$ & $2.51^{\mathrm{a}} \pm 0.11$ & $2.23 \pm 0.10$ & $2.48 \pm 0.09$ & ns & ns & $* *$ \\
\hline 14. SKNOW ${ }_{\text {Admin }}$ & $2.40^{b} \pm 0.10$ & $1.73^{a} \pm 0.10$ & $2.47^{b} \pm 0.10$ & $1.96 \pm 0.09$ & $2.44 \pm 0.08$ & $* * *$ & $* * *$ & $* * *$ \\
\hline 15. SKNOW & $3.35^{\mathrm{a}} \pm 0.11$ & $4.02^{b} \pm 0.10$ & $3.21^{\mathrm{a}} \pm 0.10$ & $3.47 \pm 0.09$ & $3.59 \pm 0.08$ & $* * *$ & ns & ns \\
\hline 16. RESPE $E_{\text {Lect }}$ & $3.30 \pm 0.11$ & $3.62 \pm 0.10$ & $3.58 \pm 0.10$ & $3.27 \pm 0.09$ & $3.73 \pm 0.08$ & ns & $* * *$ & $* *$ \\
\hline 17. RESPE $E_{\text {Repres }}$ & $2.52^{\mathrm{a}} \pm 0.12$ & $2.96^{b} \pm 0.12$ & $3.06^{b} \pm 0.12$ & $2.60 \pm 0.10$ & $3.09 \pm 0.09$ & $* *$ & $* * *$ & $* *$ \\
\hline 18. RESPE $_{\text {Admin }}$ & $2.65^{b} \pm 0.12$ & $2.33^{\mathrm{a}} \pm 0.11$ & $3.00^{c} \pm 0.11$ & $2.33 \pm 0.10$ & $2.99 \pm 0.09$ & $* * *$ & $* * *$ & $* *$ \\
\hline 19. RESPE & $3.42^{\mathrm{a}} \pm 0.10$ & $4.15^{b} \pm 0.09$ & $3.53^{\mathrm{a}} \pm 0.09$ & $3.62 \pm 0.08$ & $3.78 \pm 0.07$ & $* * *$ & ns & ns \\
\hline 20. SHARGOAL Lect & $2.84^{\mathrm{a}} \pm 0.10$ & $3.09^{\mathrm{a}} \pm 0.10$ & $3.43^{\mathrm{b}} \pm 0.10$ & $2.83 \pm 0.08$ & $3.41 \pm 0.08$ & $* * *$ & $* * *$ & ns \\
\hline 21. SHARGOAL Repres & $2.46^{\mathrm{a}} \pm 0.12$ & $2.65^{\mathrm{ab}} \pm 0.12$ & $2.85^{b} \pm 0.12$ & $2.33 \pm 0.10$ & $2.97 \pm 0.09$ & ns & $* * *$ & * \\
\hline 22. SHARGOAL ${ }_{\text {Admin }}$ & $2.55^{b} \pm 0.10$ & $1.77^{\mathrm{a}} \pm 0.10$ & $2.85^{c} \pm 0.10$ & $2.09 \pm 0.08$ & $2.68 \pm 0.08$ & $* * *$ & $* * *$ & * \\
\hline 23. SHARGOAL Class & $3.46^{\mathrm{a}} \pm 0.10$ & $4.03^{b} \pm 0.10$ & $3.46^{\mathrm{a}} \pm 0.10$ & $3.59 \pm 0.08$ & $3.71 \pm 0.08$ & $* * *$ & ns & $* *$ \\
\hline
\end{tabular}

${ }^{*} p$-value $<0.05 ;{ }^{* *} p$-value $<0.01 ;{ }^{* * *} p$-value $<0.001 ; \mathrm{ns}=$ not significantly different. ${ }^{\text {a }},{ }^{\mathrm{b}}$ Within row, averages with different superscript differ significantly.

Significant differences by level of student satisfaction were found in $65.21 \%$ of the organizational variables. $26.09 \%$ of the variables showed differences according to both criteria (Table 4). The non-significant variables were those related to the classmates and representatives of the students in the two dimensions of RC. The interactions between university and satisfaction were found in six RC variables. Most of the variables were 
related to the profile of administrative officers. The interactions found between both factors in these six significant variables are shown in Figure 1.
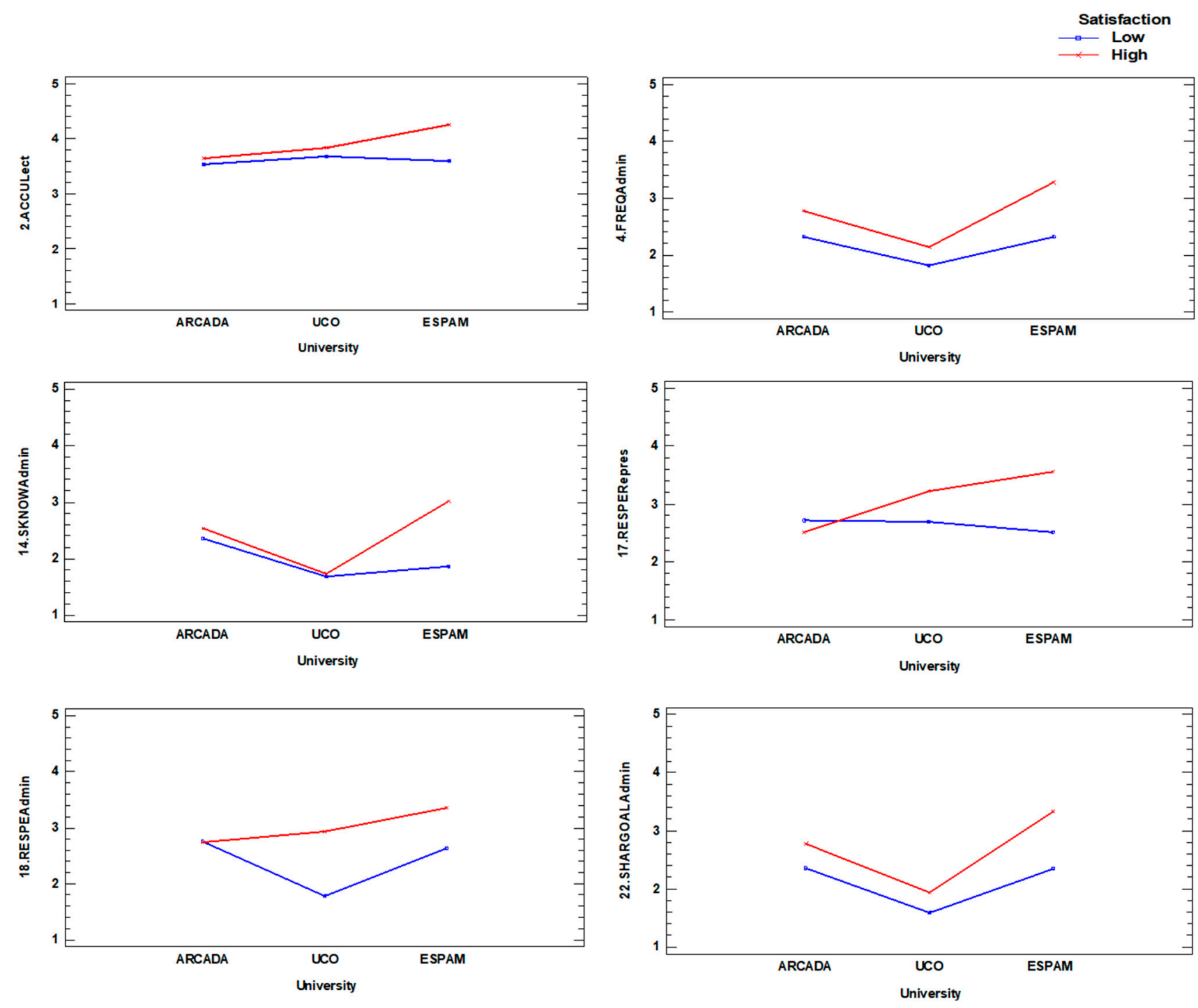

Figure 1. Interactions between university and level of satisfaction.

\subsection{Discriminant Model Building}

Discriminant analysis model among universities was carried out. As predictors, $23 \mathrm{RC}$ variables were used. The eight significant variables, which showed a $p$-value $<0.05$, were selected for the construction of the discriminant model: Three related to the communication and five to the relationship dimension (Table 5). Accurate communication with administrative officers and lecturers, shared knowledge and mutual respect with classmates; and shared objectives with the representatives of the students belonged to the discriminant model. Additionally, shared goals with lectures and administrative officers, and the communication for solving problems among classmates were the variables with the three highest discriminant powers, showing a higher F-remove coefficient. 
Table 5. Discriminant function for the organizational variables of three universities (ARCADA, UCO and ESPAM).

\begin{tabular}{ccccccc}
\hline Variable & Wilks' & Partial & F-Remove & $p$-Value & Toler & 1-Toler \\
\hline 2. ACCU $_{\text {Lect }}$ & 0.491 & 0.974 & 3.088 & $*$ & 0.603 & 0.397 \\
3. ACCU Class & 0.494 & 0.967 & 4.029 & $*$ & 0.681 & 0.319 \\
11. SOLPRO $_{\text {Class }}$ & 0.516 & 0.927 & 9.279 & $* * *$ & 0.737 & 0.263 \\
15. SKNOW $_{\text {Class }}$ & 0.493 & 0.971 & 3.568 & $*$ & 0.549 & 0.451 \\
19. RESPE $_{\text {Class }}$ & 0.494 & 0.967 & 3.960 & $*$ & 0.643 & 0.357 \\
20. SHARGOAL $_{\text {Lect }}$ & 0.518 & 0.924 & 9.726 & $* * *$ & 0.558 & 0.442 \\
21. SHARGOAL $_{\text {Repres }}$ & 0.491 & 0.973 & 3.290 & $*$ & 0.457 & 0.543 \\
22. SHARGOAL Admin $_{\text {SHA }}$ & 0.550 & 0.869 & 17.672 & $* * *$ & 0.480 & 0.520 \\
\hline
\end{tabular}

${ }^{*} p$-value $<0.05 ;{ }^{* * *} p$-value $<0.001$.

The classification matrix offered a correct ascription percentage of 69.32, obtaining assignment errors only in ESPAM (data not presented). The organizational differences of the three analyzed universities are shown in Figures 2 and 3. In the first one, in which the Mahalanobis distances obtained from the relational coordination indicators were graphically represented, a first cluster grouped ARCADA and ESPAM University and second cluster made up UCO. The students from UCO showed greater separation, and, therefore, greater relational coordination differentiation, due to its lower RC rating. The existence of different relational models for each university were observed in Figure 3, which showed a spatial distribution of each university with overlap of some individuals of ARCADA and ESPAM, but strong distance from UCO showed a clear differentiation.

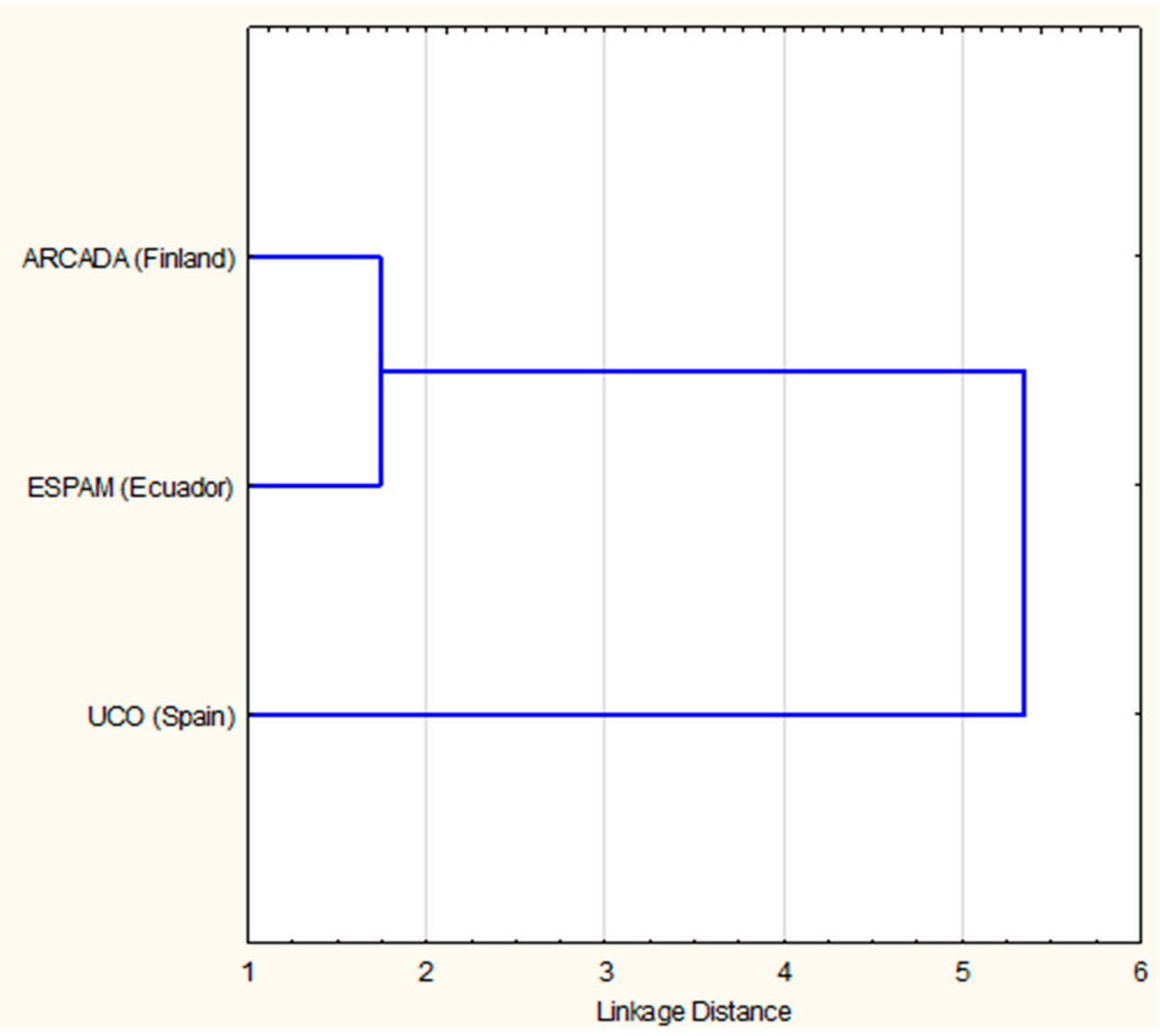

Figure 2. Cluster from Mahalanobis distances for three universities. 


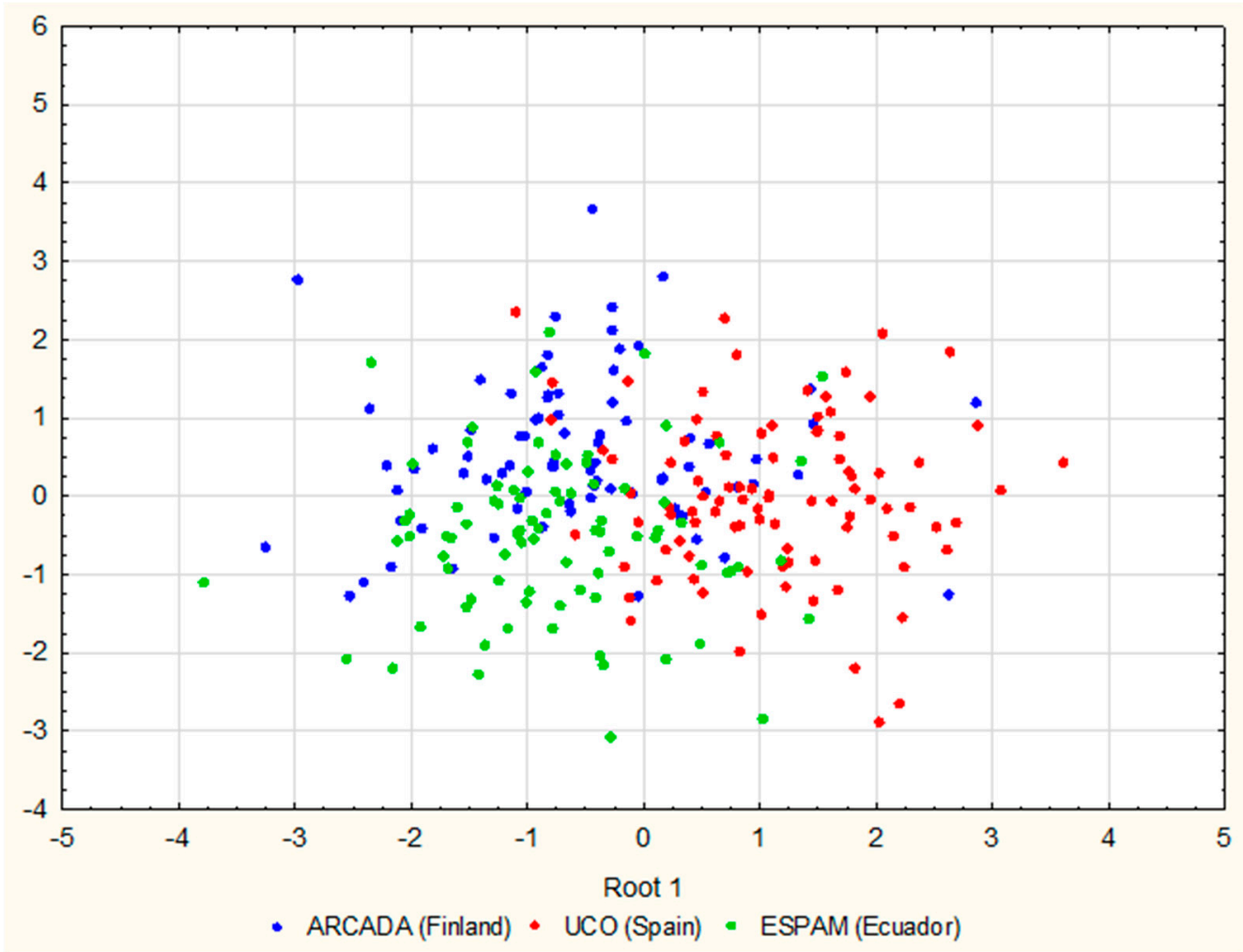

Figure 3. Plot of the individual observation discriminant scores obtained with the canonical discriminant function for three universities.

\section{Discussion}

The relational coordination framework provides an excellent basis for investigating the types of organizational models at universities [7,16,17,47]. According to [47], higher levels of relational coordination improve results. RC model can be useful to achieve excellent results in higher education where high levels of task interdependence, uncertainty, time restrictions and tacit knowledge are required [7]. In the case of higher education, it is important to identify best organizational practices to apply at universities, as well as the differences among universities, which contribute to the global knowledge of the importance of RC on the results of the organization $[16,20]$. The methodology developed in this research has allowed, in a first step, identifying the relational coordination variables that promote differences among universities and satisfaction levels. In a second stage, according to Addi-Raccah and Gavish [25], Lee and Yu [26] and Noël et al. [27], a canonical discriminant function for the ARCADA, UCO and ESPAM universities, in three countries and very different socioeconomics contexts has been built.

RQ1 was not validated in this study. According to De-Pablos-Heredero et al. [19], an improvement in organizational practices leads to an improvement in results regardless of the socioeconomic context.

RQ2 was validated, finding a positive relationship between $R C$ and student satisfaction level. In the three universities there is a positive effect between RC and satisfaction. This link is more prominent in the case of ESPAM (Figure 1). In ESPAM, with high levels of $\mathrm{RC}$, the highest values of satisfaction have been obtained. In ESPAM, which is a small size public university in a developing country with low economic growth, the level of satisfaction is very sensitive to the modifications in RC in the administrative officers profile [7]. According to the Pisa-D report [34] Ecuador requires an improvement in digital literacy, so there is a greater dependence on administrative officers [7]. Therefore, the different social contexts could explain part of the differences in organizational patterns [28]. 
Accurate and solving problem communication, mutual respect and shared knowledge and goals are strategic factors to improve de RC. The results obtained show that the personalized service to the student is positively valued by considering individual circumstances. Gallego et al. [16,17] and Margalina et al. [7] proofed how in universities with high quality levels, the institutional coordination with students was stronger. Havens et al. [15] and Haider et al. [13] paid attention to the similarities between teamwork quality and RC. Lacayo-Mendoza and De-Pablos-Heredero [48] indicated that the majority of students highly value the facilities provided by educational staff. Finally, results show that other outstanding attributes are shared goals with students' representatives and with administrative officers. Gallego et al. [16,17] and Margalina et al. [7] concluded how in universities exhibiting high quality levels, the institutional coordination with students is strong.

The construction of a discriminant model verified RQ3. Knowing the variables with the greatest discriminant power, it is possible to propose concrete, simple and economic measures to improve educational quality. The results of this research allow establishing the organizational differentiation among three Universities though discriminant analysis. Shared goals, with lectures and administrative officers, and the communication for solving problems among classmates were the variables with the highest discriminant power. UCO was the most differentiated university according to RC (Figures 2 and 3). This differentiation explains the fact that it is the highest ranked university in the world ranking of universities (Table 1).

Three different universities could be discriminated by the organizational model generated. Shared goals are a key piece for university excellence [17], therefore measures that allow sharing the objectives of the students with lectures and administrative officers are crucial. In order to enhance this, improvements are proposed in digital literacy for communication with administrative officers [7] and changes in the teaching guides, where the lectures establish specific objectives for the students in each subject, are welcomed. Solving problem communication shows that the students use the educational ecosystem in moments of lack of information [16,17]. This way, the creation of direct communication mechanisms among students and other profiles is proposed to solve the problems of university life.

Apart from this, it would be of great interest to develop prediction models for each set of organizational variables over satisfaction. This issue could be developed in future research lines by applying structural equation models. This approach could be extended to different universities and contexts.

\section{Conclusions}

This research contributes to a novel approach since it allows identifying the organizational differences among three universities with different socioeconomic contexts.

In each university, as the relational coordination dimensions are improved, the level of satisfaction increases. However, an association among universities located in countries with a higher level of economic resources and a higher level of relational coordination, has not been verified. Those universities that implement a program of best practices in relational coordination will achieve higher levels of quality in terms of student satisfaction, regardless the socioeconomic context.

The canonical discriminant model built according to the relational coordination dimensions showed that three organizational variables were enough to explain differences among universities. These variables were shared goals, with lectures and administrative officers, and the communication oriented to solve problems among classmates. Therefore, the discriminant analysis is useful for designing the improvement of the relational practices in each university.

The proposed model can easily be adapted and applied to different contexts and, therefore, they can be of great interest for the improvement of quality at universities. The results were validated but are conditioned in each university by its standard of satisfaction values. 
Supplementary Materials: The following are available online at https:/ www.mdpi.com/article/10 .3390/educsci11080445/s1, Figure S1: Statistical parameters of the student satisfaction value, Table S1: Relational coordination survey.

Author Contributions: Conceptualization and methodology, all authors. Formal analysis, software, data curation, data processing, A.L.C.; statistical analysis, C.C.-M. and S.H.; validation and investigation, C.D.-P.-H. and A.G.; supervision, A.G., C.D.-P.-H. and C.C.-M.; project administration, C.D.-P.-H. and A.G.; data acquisition, A.L.C. and A.G. All authors have been involved in developing, writing, commenting, editing and reviewing the manuscript. All authors have read and agreed to the published version of the manuscript.

Funding: This research received no external funding.

Data Availability Statement: This is not applicable as the data are not in any data repository of public access, however if editorial committee needs access, we will happily provide them, please use this email: pa1gamaa@uco.es.

Acknowledgments: We want to thank the RED-RC, the open research and innovation network for the improvement in higher education among Quevedo State Technical University (Ecuador), University of Cordoba (Spain) and Agricultural Polytechnic of Manabi "MFL" (Ecuador). The authors are thankful for the funding provided to the research project by the competitive scientific and technological research funds of Agricultural Polytechnic of Manabi "MFL" (Ecuador).

Conflicts of Interest: The authors declare no conflict of interest.

\section{References}

1. Bartimote-Aufflick, K.; Bridgeman, A.; Walker, R.; Sharma, M.; Smith, L. The Study, Evaluation, and Improvement of University Student Self-Efficacy. Stud. High. Educ. 2016, 41, 1918-1942. [CrossRef]

2. The Future of Jobs Report 2020. Available online: https://www.weforum.org/reports/the-future-of-jobs-report-2020/in-full/ (accessed on 15 July 2021).

3. Gast, I.; Schildkamp, K.; Van-der-Veen, J.T. Team-Based Professional Development Interventions in Higher Education: A Systematic Review. Rev. Educ. Res. 2017, 87, 736-767. [CrossRef]

4. Santos, J.M.; Horta, H. The Research Agenda Setting of Higher Education Researchers. High. Educ. 2018, 76, 649-668. [CrossRef]

5. Kundu, A.; Sarkar, D.N.; Bhattacharya, A. The Effect of Uncertainty on the Formulation of Strategies: A Study of Selected Indian Organizations. SN Bus. Econ. 2021, 1, 7. [CrossRef]

6. Faraj, S.; Sproull, L. Coordinating Expertise in Software Development Teams. Manag. Sci. 2000, 46, 1554-1568. [CrossRef]

7. Margalina, V.M.; De-Pablos-Heredero, C.; Montes-Botella, J.L. Achieving Quality in E-Learning through Relational Coordination. Stud. High. Educ. 2017, 42, 1655-1670. [CrossRef]

8. Fu, N.; Bosak, J.; Flood, P.C.; Ma, Q. Chinese and Irish Professional Service Firms Compared: Linking HPWS, Organizational Coordination, and Firm Performance. J. Bus. Res. 2019, 95, 266-276. [CrossRef]

9. Gittell, J.H. Coordinating Mechanisms in Care Provider Groups: Relational Coordination as a Mediator and Input Uncertainty as a Moderator of Performance Effects. Manag. Sci. 2002, 48, 1408-1426. [CrossRef]

10. Asadullah, M.A.; Haider, S.; Heredero, C.D.P.; Musaddiq, M. Effect of Ingratiation on Supervisor Satisfaction through Helping Behavior: A Moderated Mediation Model. Intang. Cap. 2016, 12, 1157-1191. [CrossRef]

11. Gittell, J.H.; Logan, C.; Cronenwett, J.; Foster, T.C.; Freeman, R.; Godfrey, M.; Vidal, D.C. Impact of Relational Coordination on Staff and Patient Outcomes in Outpatient Surgical Clinics. Health Care Manag. Rev. 2020, 45, 12-20. [CrossRef] [PubMed]

12. Haider, S.; Fernandez-Ortiz, A.; De-Pablos-Heredero, C. Organizational Citizenship Behavior and Implementation of EvidenceBased Practice: Moderating Role of Senior Management's Support. Health Syst. 2017, 6, 226-241. [CrossRef]

13. Haider, S.; De-Pablos-Heredero, C.; De-Pablos-Heredero, M. A Three-Wave Longitudinal Study of Moderated Mediation Between High-Performance Work Systems and Employee Job Satisfaction: The Role of Relational Coordination and Peer Justice Climate. Front. Psychol. 2020, 11, 792. [CrossRef] [PubMed]

14. Gittell, J.H.; Seidner, R.; Wimbush, J. A Relational Model of How High-Performance Work Systems Work. Organ. Sci. 2010, 21, 490-506. [CrossRef]

15. Havens, D.S.; Gittell, J.H.; Vasey, J. Impact of Relational Coordination on Nurse Job Satisfaction, Work Engagement and Burnout: Achieving the Quadruple Aim. J. Nurs. Adm. 2018, 48, 132-140. [CrossRef] [PubMed]

16. Sánchez, M.d.G.; De-Pablos-Heredero, C.; Merodio, J.A.M. Coordinación relacional en la educación en línea. Interciencia Rev. De Cienc. Y Tecnol. De Am. 2015, 40, 869-874.

17. Gallego, M.d.C.; De-Pablos-Heredero, C.; Medina-Merodio, J.-A.; Robina-Ramírez, R.; Fernandez-Sanz, L. Relationships among Relational Coordination Dimensions: Impact on the Quality of Education Online with a Structural Equations Model. Technol. Forecast. Soc. Chang. 2021, 166, 120608. [CrossRef] 
18. De-Pablos-Heredero, C.; Díaz-Ocampo, E.; Torres, Y.; Checa, C.; Barba, C.; García, A. Typology of relational coordination model in higher education: The case of universidad tecnica estatal de quevedo-ecuador. In EDULEARN19 Proceedings; IATED: Valencia, Spain, 2019; pp. 9616-9620.

19. De-Pablos-Heredero, C.; Díaz-Ocampo, E.; Torres, Y.; Checa, C.; Barba, C.; García, A. Organizational quality level of universidad tecnica estatal de quevedo-ecuador. In INTED2020 Proceedings; IATED: Valencia, Spain, 2020; pp. 4921-4925.

20. Checa, C.; De-Pablos-Heredero, C.; Torres, Y.G.; Montes-Botella, J.L.; Barba, C.; García, A. Focused Coordination Models towards Sustainability in Higher Education. Case of Quevedo State Technical University (Ecuador). Sustainability 2020, 12, 5760. [CrossRef]

21. Caffarel-Serra, C.; Ortega-Mohedano, F.; Gaitán-Moya, J.-A. Investigación en Comunicación en la universidad española en el período 2007-2014. Prof. De La Inf. 2017, 26, 218-227. [CrossRef]

22. Zee, M.; Koomen, H.M.Y. Teacher Self-Efficacy and Its Effects on Classroom Processes, Student Academic Adjustment, and Teacher Well-Being: A Synthesis of 40 Years of Research. Rev. Educ. Res. 2016, 86, 981-1015. [CrossRef]

23. Ortega-Mohedano, J.; Rodríguez-Conde, M.J. Which Is or Should Be the Ideal Level of Participation of Students of Higher Education in Their Own Education?A Theoretical Model of Relations between the University and Their Students and the Quality of Higher Education. In Proceedings of the Sixth International Conference on Technological Ecosystems for Enhancing Multiculturality, Salamanca, Spain, 24 October 2018; ACM: New York, NY, USA; pp. 190-198.

24. Kilgo, C.A.; Culver, K.C.; Young, R.L.; Paulsen, M.B. The Relationship Between Students' Perceptions of “Good Practices for Undergraduate Education" and the Paradigmatic Development of Disciplines in Course-Taking Behavior. Res. High. Educ. 2017, 58, 430-448. [CrossRef]

25. Addi-Raccah, A.; Gavish, Y. The LEA's Role in a Decentralized School System: The School Principals' View. Educ. Manag. Adm. Leadersh. 2010, 38, 184-201. [CrossRef]

26. Lee, S.; Yu, J. Discriminant Model of BIM Acceptance Readiness in a Construction Organization. KSCE J. Civ. Eng. 2017, 21, 555-564. [CrossRef]

27. Noël, N.M.; Trocchia, P.; Luckett, M. A Predictive Psychometric Model to Identify Personality and Gender Differences of College Majors. Int. J. Manag. Educ. 2016, 14, 240-247. [CrossRef]

28. Bush, T. Preparation and Induction for School Principals: Global Perspectives. Manag. Educ. 2018, 32, 66-71. [CrossRef]

29. Finlandia I Ranking Web de Universidades: Webometrics Clasifica 30000 Instituciones. Available online: https: / webometrics. info/es/Europe_es/Finlandia (accessed on 8 August 2021).

30. España | Ranking Web de Universidades: Webometrics Clasifica 30000 Instituciones. Available online: https: / / webometrics.info/ es/Europe_es/Espa\%C3\%B1a (accessed on 8 August 2021).

31. Ecuador I Ranking Web de Universidades: Webometrics Clasifica 30000 Instituciones. Available online: https: / webometrics. info/es/Latin_America_es/Ecuador (accessed on 8 August 2021).

32. Organisation for Economic Co-operation and Development. The Programme for International Student Assessment (PISA). Results from PISA 2018, Finland; Organisation for Economic Co-operation and Development: Paris, France, 2019 ; p. 10.

33. Organisation for Economic Co-operation and Development (OECD). The Programme for International Student Assessment (PISA). Results from PISA 2018, Spain; Organisation for Economic Co-operation and Development (OECD): Paris, France, 2019 ; p. 9.

34. Organisation for Economic Co-operation and Development (OECD). Educación En Ecuador. Resultados Del Informe PISA Para El Desarrollo 2018; Organisation for Economic Co-operation and Development (OECD): Paris, France, 2019; p. 152.

35. World I Ranking Web of Universities: Webometrics Ranks 30000 Institutions. Available online: https://www.webometrics.info/ en/WORLD (accessed on 15 July 2021).

36. Ranking \& Subjects. Available online: https:/ /www.umultirank.org/study-at/arcada-university-of-applied-science-rankings / (accessed on 15 July 2021).

37. University of Córdoba. Available online: https://www.timeshighereducation.com/world-university-rankings/universitycordoba (accessed on 15 July 2021).

38. ShanghaiRanking-Univiersities. Available online: http://www.shanghairanking.com/institution/university-of-cordoba (accessed on 15 July 2021).

39. Universidad de Córdoba. Available online: https://www.topuniversities.com/universities/universidad-de-cordoba/undergrad (accessed on 15 July 2021).

40. Ecuador Categorías de Universidades LISTADO 2021. Available online: https://informacionecuador.com/listado-categorias-deuniversidades-ceaaces / (accessed on 15 July 2021).

41. Méndez, D.; Macía, F. Análisis factorial confirmatorio de la escala de actitudes hacia la estadística. Cuad. De Neuropsicol. 2007, 1, 337-345.

42. Reips, U.-D.; Funke, F. Interval-Level Measurement with Visual Analogue Scales in Internet-Based Research: VAS Generator. Behav. Res. Methods 2008, 40, 699-704. [CrossRef]

43. Gutiérrez-Cordero, M.L.; Segovia-Vargas, M.J.; Escamilla, M.R. Análisis del Riesgo de Caída de Cartera en Seguros: Metodologías de "Inteligencia Artificial" vs "Modelos Lineales Generalizados". Econ. Inf. 2017, 407, 56-86. [CrossRef]

44. Rivas, J.; Manuel Perea, J.; De-Pablos-Heredero, C.; Morantes, M.; Angon, E.; Barba, C.; García, A. Role of Technological Innovation in Livestock Breeding Programmes: A Case of Cereal-Sheep System. Ital. J. Anim. Sci. 2019, 18, 1049-1057. [CrossRef]

45. Legendre, P.; Legendre, L. Chapter 11—Canonical analysis. In Developments in Environmental Modelling; Legendre, P., Legendre, L., Eds.; Numerical Ecology; Elsevier: Amsterdam, The Netherlands, 2012; Volume 24, pp. 625-710. 
46. Rencher, A.C. Interpretation of Canonical Discriminant Functions, Canonical Variates and Principal Components. Am. Stat. 1992, 46, 217-225. [CrossRef]

47. Lacayo-Mendoza, A.; De-Pablos-Heredero, C. Managing Relationships and Communications in Higher Education Efficiently through Digital Social Networks: The Importance of the Relational Coordination Model. DYNA Rev. De La Fac. De Minas. Univ. Nac. De Colombia. Sede Medellín 2016, 83, 138-146. [CrossRef]

48. De-Pablos-Heredero, C.; Haider, S.; Martinez, A.G. Relational Coordination as an Indicator of Teamwork Quality: Potential Application to the Success of e-Learning at Universities. Int. J. Emerg. Technol. Learn. 2015, 10, 4-8. [CrossRef] 